PRODUCTION

ENGINEERING

ARCHIVES
2015, Vol. 8, No.3, pp 18-21

ISSN 2353-5156 (print version)

ISSN2353-7779 (online version)

\begin{tabular}{|c|c|c|}
\hline Article history: & Received: 28.08.2015 & Accepted: 17.09 .2015 \\
\hline
\end{tabular}

\title{
Influence of antimony modification and heat treatment on the AISi9CuMnNi alloy
}

\author{
Nataša Náprstková ${ }^{1}$, Jaromír Cais $^{2}$, Jan Sviantek $^{3}$ \\ ${ }^{1}$ Faculty of Production Technology and Management, Jan Evangelista Purkyně University in Ústínad Labem, Pasteurova 1, 40096 Ústínad \\ Labem, Czech Republic, +420 475285 513, naprstkova@fvtm.ujep.cz \\ ${ }^{2}$ Faculty of Production Technology and Management, Jan Evangelista Purkyně University in Ústínad Labem, Pasteurova 1, 40096 Ústínad \\ Labem, Czech Republic, +420 475285 545, cais@fvtm.ujep.cz \\ ${ }^{3}$ Faculty of Production Technology and Management, Jan Evangelista Purkyně University in Ústínad Labem, Pasteurova 1, 40096 Ústínad \\ Labem, Czech Republic, +420 475285 513, sviantek@fvtm.ujep.cz
}

\begin{abstract}
Modification of alloys is an important part of the metallurgical process, and this also applies to aluminum alloys, particularly for Al-Si (silumins). As a modification of the material we can utilise the modification using the selected element or heat treatment of alloys, or a combination of both processes. One of the elements that it is possible to modify the alloy of Al-Si used is antimony (Sb). The paper examines the possible effect of the modification of that element and heat treatment on the final structure of the alloy AlSi9CuMnNi and other selected properties after machining. In the experiments three castings from the alloy AlSi9CuMnNi were made without modification, three castings with the modification and without heat treatment, three castings with modification and without heat treatment, and three castings with modification and heat treatment. The described experiment and analysis are part of extensive research undertaken at Faculty of Production Technology and Management, J. E. Purkyně University in Ústínad Labem.
\end{abstract}

Key words - Aluminium alloy, modification heat treatment, manufacturing

\section{Introduction}

Generally, alloys are modified and thermally processed to improve their chosen technological properties. This applies to aluminum alloys and specifically alloys based on Al-Si, called Silumins (BOLIBRUCHOVÁ, D. 2005, LIPIŃSKI,T. 2011).

Alloy AlSi9CuMnNi, which will be investigated, falls into the group of alloys based $\mathrm{Al}-\mathrm{Si}$. Within experiments FPTM this alloy was modified by 0.2 wt. \% Antimony, and by heat treatment processed, too. (TILlOVÁ, E., 2013, RoUČKA, J., 2004)

The investigated alloy was also heat-treated. Heat treatment of aluminum and its alloys can be in the sense for CSN 420056 defined as the process by which a product or product parts in solid state is subjected to one or more cycles of annealing to achieve the desired structure or substructure and properties (MICHNA Š. 2005).

As part of the experiments tool wear of insert after the turning of experimental samples were made (Kocman, K. 2011, DUGIN, A. 2012).

The alloy was at FPTM JEPU made of individual ingredients and there are no master alloys. In Tab. 1 it is the basic composition of this alloy. 
Tab. 1 Content of alloying elements in the alloy

\begin{tabular}{|c|c|c|}
\hline Element & Range [wt. \%] & Chosen [wt. \%] \\
\hline $\mathrm{Si}$ & 10 & 10 \\
\hline $\mathrm{Cu}$ & $0.8-1.2$ & 1 \\
\hline $\mathrm{Mn}$ & $0.6-0.8$ & 0.7 \\
\hline $\mathrm{Ni}$ & $0.8-1.2$ & 1 \\
\hline
\end{tabular}

\section{Introduction}

For the experiment castings from alloy AlSi9CuMnNi were made, a total of twelve castings. They were divided into four groups of three castings. The first group of castings has not been modified or thermally processed. The second group was modified antimony without further heat treatment. The third group of castings were heat treated without modification antimony. The last group was modified antimony with subsequent heat treatment.

The alloy AlSi9CuMnNi was made at FPTM from individual components and not applied to the master alloy. For the modification 0.2 wt. \% Antimony (Sb) was used.

Besides modification the part of the castings was also heat treated. As a kind of heat treatment solution annealing leading to an increase in material hardness and uniformity of the chemical composition. In the first part, the hardening of the material supercritical cooling, and in the second part of the artificial aging. The entire course of the heat treatment process took approximately 16 hours. First, the samples were heated in the melting furnace for a certain time. The next stage was rapid cooling in a water bath, and samples were then put into a drying furnace for the rest of the process. The drying furnace was set to turn off automatically after six hours at a temperature of $160^{\circ} \mathrm{C}$, cooling of the samples was carried in the shutdown of the furnace.

Test samples were machined on a lathe Emco Mat $14 \mathrm{~S}$, which is at the FPTM available. (NÁPRSTKOVÁ N. 2012)Set cutting conditions were based primarily on the type of machine and tool. Cutting tools used were plates (inserts) PRAMET DCMT 070202 E - UR and based on the material to be machined and used machine and tool was set depth of cut $a_{p}=1 \mathrm{~mm}$ and feed per revolution $f=0,12 \mathrm{~mm} \cdot \mathrm{rev}^{-1}$. Cutting speed $v_{c}$ was necessary to adapt the options of used lathe Emco Mat - 14 S, particularly its maximum rotation speed $n$. Cutting plate was clamped at the outer bracket SDJCR 1212 F 07 KT 016. All the working conditions for the machining are set to achieve the maximum load inserts.

\section{Realized analyses}

For checking the correct chemical composition of the samples a spectrographic analysis was carried out. The composition of the samples was examined equipment INNOV Delta X, several randomly selected samples were analyzed for comparison by using equipment Q4 Tasman. (KALINCOVÁ D. 2010)

The results of spectrographic analysis carried out on samples No. 1 to 6, which have not been modified antimony, showed that during the production of castings a certain quantity of manganese and nickel in the alloy were lost. For samples that have been modified antimony, it is again evident that a certain quantity of manganese and nickel decreases. There was also a slight decrease in antimony.

For determining the effect of heat treatment and $\mathrm{Sb}$ modification to the alloy AlSi9CuMnNi microscopic analysis was carried out.

At first samples of the alloy which had not been modified with antimony or the material heat treatment taken place, were taken (Fig. 1). The structure of all samples without modification and heat treatment was very similar. Silicon needles were relatively large and irregularly arranged.

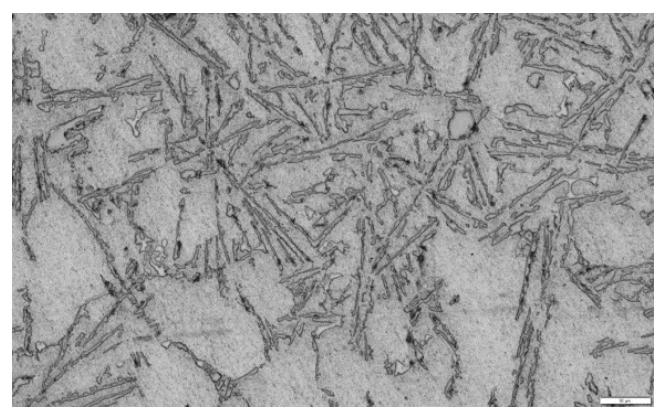

Fig. 1.Example of structure unmodified casting, mag. $100 x$

Further samples were analyzed without modification antimony, but after heat treatment. The example of microstructure of these samples is shown in Fig. 2. On the microstructure more uniform distribution needles of silicon are evident.

Other evaluated samples were modified antimony, but without heat treatment. The example of structures is shown in Fig 3. From this it is evident that modification to the microstructure is significantly affected and the modifying effect of antimony can therefore be seen. 


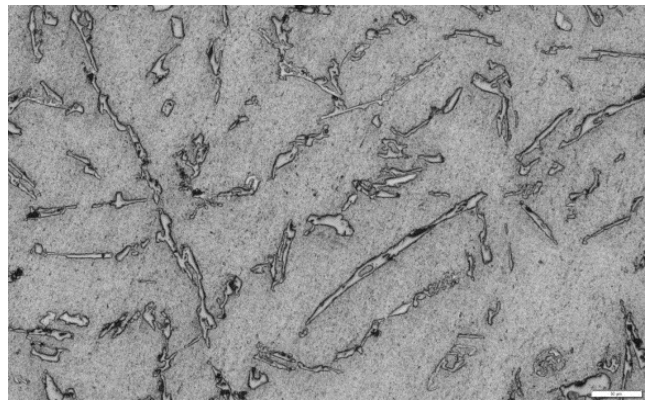

Fig. 2.Example of structures of the unmodified casting after thermal processing, mag. $100 x$

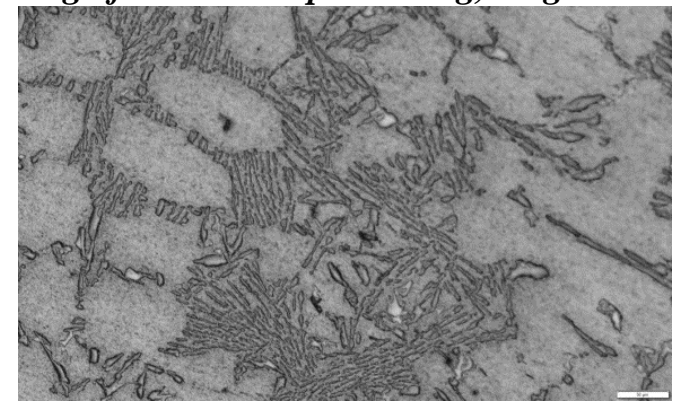

Fig. 3.Example of structure modified casting, mag. $100 x$

The last samples were evaluated, which have been modified and have undergone thermal treatment. On Fig. 4 is examples of obtained structures. This modifying effect of antimony is apparent and also an effect of heat treatment on the more uniform distribution of structure. Silicon particles are finer and have rounded edges.

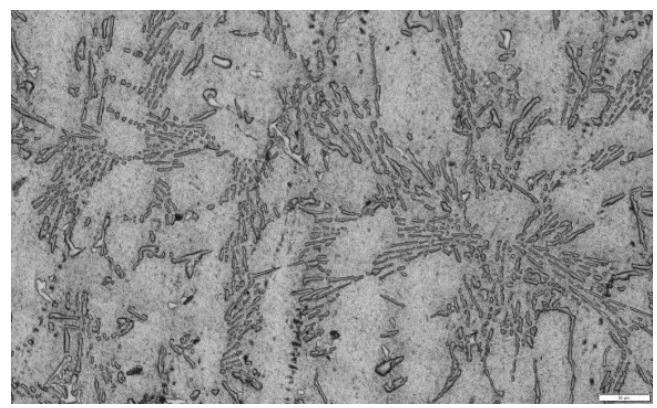

Fig. 5. Example of structure modified casting after heat treatment, mag. $100 x$

Generally the occasional occurrence of porosity can be observed in castings, which is a consequence of casting technology. All samples were prepared by gravitational casting.

Each area for measuring of tool wear is shown inFig. 6. Evaluation was carried out according to characteristics of the standard ISO3685. (SUCHÁNEK D. 2011,
VALÍČEKJ. 2008) For measurement the software QuickPHOTO CAMERA 3.2 was used.

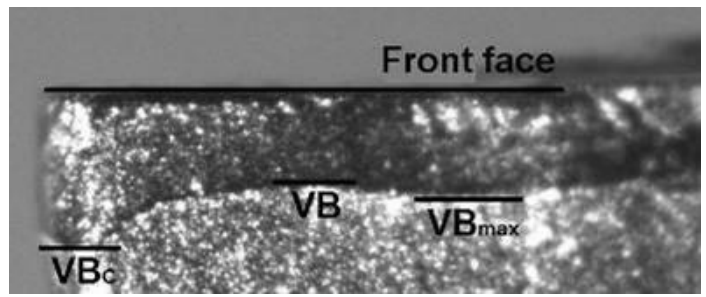

Fig. 6.The principle of measurement of wear values of cutting plate(insert)

In Fig. 7 is the graph of measured results of wear in the back area of the tool (VBc, VB, VBmax).

From this graph it is apparent that the order of tool wears for each group of samples in all parameters (VB, $\mathrm{VBc}, \mathrm{VBmax}$ ) are identical. As the heat treatment, as well antimony as a modifier according to the measured results had a favorable, even if relatively small effect on the size of the tool wear.

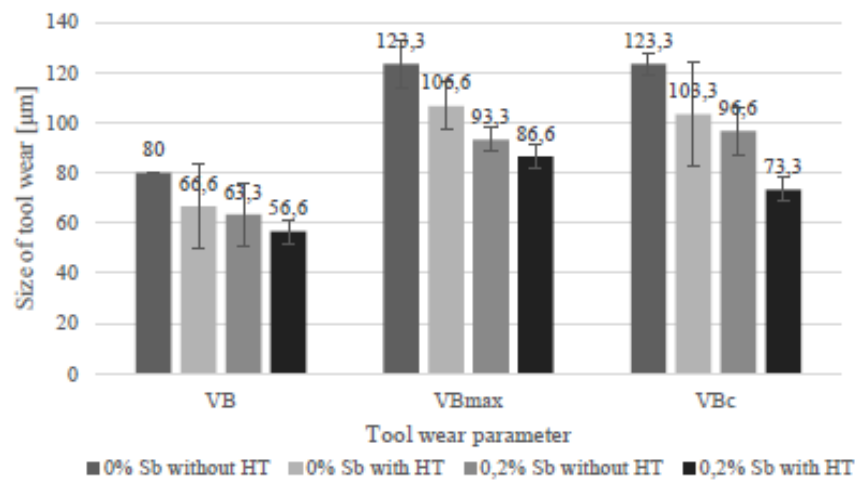

Fig. 7.Average tool wear

\section{Conclusion}

For this experiment a total of four kinds of castings were carried out (the castings without heat treatment and without modification antimony, castings without heat treatment and modified antimony, castings with heat treatment without modification antimony and castings with heat treatment and modified antimony). Antimony was dosed in pure form in an amount of $0.2 \mathrm{wt}$. $\%$. As the heat treatment was applied solution annealing for more uniform structure with subsequent hardening.

A spectrometric analysis was carried out for controlling the resulting composition of the castings. The next step of the experiment was to analyze the microstructure 
of castings. For samples with thermal treatment the effect of processing on the uniformity of the microstructure was detectable. A very significant impact on the microstructure had the modification by antimony. Microstructure eutectics was formed consisting of fine particles of silicon in $\alpha$ phase. Due to the modification effects of antimony finer and partly curved needles silicon were formed which should have a positive effect on the properties of the material.

The next step was to evaluate the wear inserts after turning. VB, VBc and VBmax were measured according to standard ISO 3685. From the measured values it shows that the positive effect on the tool wear has not only the antimony, but especially the heat treatment. Most worn plates were used for turning cast without heat treatment and without antimony. Conversely, the least worn plates were used for turning castings after heat treatment with modification by antimony. Beyond the positive effect on tool wear the positive effect of antimony on the built-up edge was also observed.

The presented results are part of larger research carried out at FPTM JEPU.

\section{Acknowledgement}

Authors are grateful for the support of grant SGS 2014 UJEP and of grant OP 2.2 No. CZ.1.07/2.2.00/28.0296.

\section{Literature}

1. Bolibruchová, D., Tillová, E. 2005. Zlievarenskézliatiny Al-Si(Casting alloys Al-Si)ŽU in Žilina. Žilina. EDIS. ISBN 80-8070-485-6

2. Dugin, A., Popov, A. 2012Effect of the cutting tool wear on the ploughing force value.InStrojirenská technologie (In Production Technology). Vol. 17, No.1,2, pp. 19-23. ISSN 1211-4162.

3. KALINCOVÁ, D. 2010 Skušanie mechanických vlastností materiálov - prehlad meracich metod a zariadeni (Testing of mechanical properties of materials - overview of measuring methods and devices). KEGA 3/6370/08., TU vo Zvolene, Zvolen, p.13-26.

4. KoCMAN, K. 2011 Technologicképrocesyobráběni (Technological manufacturing processes). Brno. CERM.
5. LIPIŃSKI T. 2011 Microstructure and Mechanical Properties of the AlSil3MglCuNi Alloy with Ecological Modifier. In Manufacturing Technology. Vol. 11, pp 40-44. ISSN 1213-2489.

6. MichNA, Š., LUKÁČ, I., OČENÁŠEK, V., KOŘENÝ, R., DRÁPAlA, J., SCHNEIDER, H., MišKUfOVÁ, A. and coll. 2005. Encyklopediehliníku (Encyclopedia of Aluminium). Adin, Prešov, ISBN 80-89041-884.

7. NÁPRSTKOVA, N. 2012 Vlivočkováníslitiny AlSi7Mg0,3 očkovadlem AlTi5B1 naopotřebeninástrojepríijejimobrábění. (Influence of Inoculation AlTi5B1 on the AlSi7Mg0,3 Alloy and its Tool Wear During its Machining). InStrojírenská technologie(In Production Technology). Vol. 17, 2012, No. 5,6, pp. 330-338. ISSN 1211-4162.

8. RoUČKA, J. 2004 Metalurgieneželeznýchslitin (Metallurgy of non-ferrous alloys). Brno, CERM, 148 p. ISBN 80-214-2790-6.

9. SUCHÁNEK, D., DUŠÁK, K. 2011 Impact of cutting conditions on tool wear.In Strojírenská technologie (In Production Technology). Vol. 16, No.5, pp. 33-37, ISSN 1211-4162.

10. Tillová, E., Farkašová, M., Chalupová, M. 2013. The Role of Antimony in Modifying of Al-Si$\mathrm{Cu}$ Cast Aloy.In Manufacturing Technology, Vol. 13, No. 1, pp. 109-114, ISSN 1213-2489.

11. VALÍČEK, J., RuSNÁK, J., MÜller, M., HRABĚ, P., KADNAR, M., HLOCH, S., KUŠNEROVÁ, M. 2008 Geometrické aspekty drsnosti povrchu klasických a netradičnich technologii (Geometrical aspects of surface roughness of classic and innovative technologies). In Jemná mechanika a optika (In Precision Mechanics and Optics), Vol.53, No.9, p.249253. 